\title{
Clinical and Laboratory Aspects of the Severity of Pulmonary Embolism in Elderly Patients versus Adult Patients A single centre study
}

\begin{abstract}
ADINA FLAVIA MORGOVAN ${ }^{1 \#}$, VLAD SABIN IVAN" ${ }^{1 \#}$, DANA ROXANA BUZAS ${ }^{1 *}$, MELANIA ARDELEAN ${ }^{1}$, NICOLAE ALBULESCU $^{2 *}$, DANIEL FLORIN LIGHEZAN" ${ }^{1 *}$, RARES OLARIU4 ${ }^{4}$, OVIDIU MEDERLE ${ }^{5}$, SIMINA CRISAN ${ }^{3}$, LUCIAN PETRESCU ${ }^{3 *}$

${ }^{1}$ Victor Babes University of Medicine and Pharmacy Timisoara, Department V Internal Medicine I, 2 Eftimie Murgu Sq., 300041, Timisoara, Romania

Victor Babes University of Medicine and Pharmacy Timisoara, Department VII Internal Medicine II, 2 Eftimie Murgu Sq., 300041, Timisoara, Romania

${ }^{3}$ Victor Babes University of Medicine and Pharmacy Timisoara, Department VI Cardiology, 2 Eftimie Murgu Sq., 300041, Timisoara, Romania

4Victor Babes University of Medicine and Pharmacy Timisoara, Department XIII Infectious Diseases, 2 Eftimie Murgu Sq., 300041, Timisoara, Romania

${ }^{5}$ Victor Babes University of Medicine and Pharmacy Timisoara, Department IX Surgery I, 2 Eftimie Murgu Sq., 300041, Timisoara, Romania

Pulmonary thromboembolism is currently one of the leading causes of disease burden and mortality in Europe, also known as the great masquerader, for its ability to mimic other diseases or to present itself with few symptoms, especially when the pulmonary embolism is very small. With aging population, increased survival of cancer patients and the addition of multiple debilitating diseases such as dementia, heart failure, chronic kidney disease the rate of pulmonary embolism is spiking, with more and more small pulmonary embolism being diagnosed, that may have no immediate impact on mortality, but which may contribute to an increase in morbidity. We have examined retrospectively 108 consecutively cases of pulmonary thromboembolism that have presented in the Emergency Department of Municipal Hospital in Timisoara, Romania over the course of twenty-one months from September 2016 to May 2018 and we evaluated the clinical and laboratory findings in studying the influence of age over the severity of pulmonary embolism.
\end{abstract}

Keywords: pulmonary embolism, biomarkers, prediction, cardiac dysfunction

Pulmonary embolism (PE) is a leading cause of death with a worldwide increase in the number of cases with even more cases being diagnosed in the postmortem setting [1].

This increase is attributable to a series of factor associated with ageing, increased cancer incidence and cancer survival, chronic diseases such as chronic kidney disease, chronic obstructive pulmonary disease, dementia etc. For example, for year 2005, Cohen et al [2] attributes to pulmonary embolism a staggering number of over 317000 deaths in only 6 countries across the European Union.

Pulmonary embolism is colloquially known as the great masquerader, because it can mimic other clinical entities such as pneumonia or heart attack or can present itself with limiting and no clear symptoms, many of them being nonspecific. The most frequent symptoms are dyspnea, cough, pleuritic chest pain, substernal chest pain and fever, with the almost half of the patients presenting with dyspnea. Only a third of patients present themselves with chest pain, either pleuritic or substernal, a quarter with cough and only about one in ten have fever [3]. Because of the scarcity of signs and symptoms, scores were developed in order to evaluate probability of a patient having pulmonary embolism. The scores have an advantage over clinical judgment, of being objectively validated. Scores such as Wells criteria and the revised Geneva score are a useful tool in guiding the initial approach to a patient with suspected pulmonary embolism [4]. Both of these validated scores were even more simplified for use in an emergency setting, with a probability of diagnosing a patient with pulmonary embolism ranging from around $10 \%$ in the low probability case to over $65 \%$ in a case with high probability based on these score [3].

A recentstudy for evaluating the probability of pulmonary embolism using the simplified Geneva score of 1621 patients with age-adjusted D-dimer showed that overall pulmonary embolism was confirmed in 294 patients (18.1\%). $60.5 \%$ of the patients were classified as intermediate risk of having pulmonary embolism and $2 \%$ as having high probability with the rest as low probability. This study has shown that even a simplified version of the probability scores is at least as efficient as the standard score in predicting the risk of pulmonary embolism when associated with the D-dimer test [5].

\section{Objective}

The objective of this retrospective study is to evaluate the clinical and laboratory finding regarding the severity of pulmonary embolism in consecutive elderly and adult patients diagnosed with pulmonary embolism.

\section{Experimental part}

Materials and method

We have reviewed 108 consecutive patients that were diagnosed with pulmonary embolism, irrespective of etiology, in the Emergency Department (ED) of Municipal Emergency Hospital in Timisoara, Timis County, Romania during a 22 month period starting with September 2016 until May 2018.

The PE was diagnosed in the emergency unit by emergency physicians based on clinical judgement, 
physical findings and laboratory markers, supported by the use of either Wells criteria or the revised Geneva score. All cases had chest CT angiography in accordance with the current European Society of Cardiology (ESC) guideline recommendations for PE. Estimated glomerular filtration rate was calculated using the CKD-EPI creatinine equation (2009) and patients with eGFR $<15 \mathrm{ml} / \mathrm{min}$ were excluded, because the chest angiography could not be performed without the risk of contrast induced lesions.

The assay for the measurement of the cardiac enzymes that was used, was an $24 \mathrm{~h}$ available and calibrated BIOSITE $\circledast$ Triage MeterProand, that analyzed creatinephosphokinase MB iso-enzyme (CK-MB, normal value between 0 and $4.3 \mathrm{ng} / \mathrm{mL}$ ), myoglobin (MYO, normal value between 0 and $107 \mathrm{ng} / \mathrm{mL}$ ), troponin I (TNI, normal value between 0 and $40 \mathrm{ng} / \mathrm{mL}$ ), brain natriuretic peptide (BNP, the normal value range was between 0 and $100 \mathrm{pg} / \mathrm{mL}$ ) and D-dimers (normal range between 0 and $500 \mathrm{pg} / \mathrm{mL}$ ). Also the ED complete blood count was further included in our analysis. The at least likely possibility of PE was enough to perform an immediate assay. If the blood sample could notbe analyzed or resulted in an error, another blood sample was taken and subjected for analysis on the same device.

A careful history was performed with focus on past diseases, recentimmobilization, recent surgery, recentbed riddance, cancer history, blood coagulation disorders, anticoagulation drugs and other chronic medications, recurrent VTE, history of heart failure, atrial fibrillation, chronic obstructive pulmonary disease. We also searched our database for these patients to find if they were admitted before for other causes and if there subjected to any recent hospitalizations. All patients had a PESI score calculated and the therapy was guided based on this score, as all of the patients diagnosed with PE were admitted and none was discharged from the ED, even if after they were early discharged.

For our analysis we divided the patients in 3 groups, based on the site of pulmonary embolism. The first group named CT PROX comprised the patients with massive PE that either required thrombolysis or the clot was in the pulmonary trunk or one of the main pulmonary artery, the second group named CT LOBAR comprised patients with non massive $P E$, but at least one lobar branch affected and the third group named CT DISTAL, consisted of PEs in the smaller branches, but no larger than segmental branches. These patients were further divided based on their age in two groups, the cut-off age being 65 years old.

The Ethics Committee of the Victor Babes University of Medicine and Pharmacy, Timisoara, Romania, approved the study in complete accordance with the Declaration of Helsinki.

\section{Statistical analysis}

For the statistical analysis the IBM SPSS Statistics for Windows version 20.0 software was employed, with a significance level considered when $p<0.05$. Mean, interquartile range, median, and standard deviation were among the analyzed variables, which were further included in figures and tables for better and easier understanding of the data. For correlations between the most important data we made use of Spearman correlation coefficient.

\section{Results and discussions}

Following our research, we have identified 108 patients that were included in our analysis. Out of these, 51 were males (47.22\%), the mean age of the group was 64.18 years, with a median of 66 years, the youngest being 22 years old and the oldest 92 years old. The majority of the patients had no prior DVT and no history of angina pectoris. A total of 8 patients, representing about $7.4 \%$, presented or developed shorthly after (in the first 24 hours) circulatory failure. The mean calculated PESI score was equivalent to class III PESI with, 97.6 points, with more than $75 \%$ having a SPESI of more than 1 point. Based on PESI risk category, the number of patients attributed to classes I and II representing low risk, classes III and IV representing intermediate risk, and class $\mathrm{V}$ representing high risk were $41(37.96 \%), 45(41.67 \%)$, respectively $22(20.37 \%)$. The mean body mass index was $28.21 \mathrm{~kg} / \mathrm{m}^{2}$ body surface, with a median of $26 \mathrm{~kg} / \mathrm{m}^{2}$ body surface, most of the patients being overweight and obese. Summary of baseline characteristics are presented in Table 1.

We also divided the patients based on their age, in two categories, younger and older than 65 years, out of which 64 patients $(59.26 \%$ ) were elderly patients ( 65 years of age or older). For the elderly patients, PESI values ranged from 67 to 202, with a median value of 98.5 , an interquartile range (Q1-Q3) of 86.5-121 and a mean (standard deviation) value of 109.69 (33.158). The most frequently PESI score recorded for our elderly patients was 102. In Table 2 the comparison between main baseline and disease characteristics of adult and elderly patients is summarized with statistical significance achieved for PESI related score and risk category for aged patients.

When we analyzed the comorbidities of elderly patients versus adult patients using the t-test and Chi-square none of the parameters obtained statistical significance, even if the incidence of symptoms and comorbidities is higher in the elderly group. Results are summarized in Table 3.

The complete blood count showed that there was a small direct correlation with the hemoglobin level, butonly in elderly patient with massive PE we observed a statistically significant result as shown in Table 4 and figure 1. No correlation was obtained with leucocytes and RDW.

Pulmonary embolism is often a silent killer and can affect patients of all ages as in our study the youngest one was only 22 years old, while the oldest was 92 years old. In the younger patients, genetic causes such as thrombophilia states, trauma or immobilization and some hematological malignancies are the diseases that account for most of the cases, for the elderly and adults DVT, immobilization, surgery and solid and lymphatic cancers are the predominant causes [6].

Elderly patients din not have any statistical significance regarding their symptoms and comorbidities, several other studies confirming these findings. Masotti et al [11], reported that diagnosing PE in the elderly is difficult and unexplained dyspnea, tachycardia, tachypnea should warrant a chest CT angiography to exclude this diagnosis. In our study over $96 \%$ of elderly patients complained of dyspnea, chest pain and, palpitations, and cough being of lesser frequency, butstill higher than in adult patients [12].

When accounting for the severity of the PE our study had a mean PESI of approximately 98 points, representing a class III intermediate risk with more than three quarters of them having an SPESI of more than 1 . Although a sPESI of 0 points has negligible risk (overall low risk of mortality of $1.1 \%$ or severe morbidity of $1.5 \%$ ), a SPESI of $\geq 1$ increases the risk to a high risk of mortality (8.9\%)or severe morbidity $(2.7 \%)$ all of our patients selected in this study were admitted to the hospital for further evaluation.

Our baseline characteristics and patient comorbidities are quite similar to other studies [7] with heart failure, chronic pulmonary disease and obesity being the most frequent associated comorbidities. We note that although the outright proportion of obese patients is lower, the mean 


\begin{tabular}{|c|c|}
\hline Baseline characteristics & $\begin{array}{l}\text { All patients } \\
(\mathrm{N}=108)\end{array}$ \\
\hline $\begin{array}{l}\left.\text { Age(years) }{ }^{\circ}\right) \\
\text { Mean }(S D) \\
\text { Min; Max } \\
\text { Median }(Q 1 ; Q 3)\end{array}$ & $\begin{array}{l}64.18(16.541) \\
22 ; 92 \\
66(56.0 ; 77.5)\end{array}$ \\
\hline $\begin{array}{l}\text { Gender } \\
\text { Male } \\
\text { Female }\end{array}$ & $\begin{array}{l}51(47.22 \%) \\
57(52.78 \%)\end{array}$ \\
\hline $\begin{array}{l}\text { Angor } \\
\text { No } \\
\text { Yes }\end{array}$ & $\begin{array}{l}86(79.63 \%) \\
22(20.37 \%)\end{array}$ \\
\hline $\begin{array}{l}\text { Vascular failure } \\
\text { No } \\
\text { Yes }\end{array}$ & $\begin{array}{l}100(92.59 \%) \\
8(7.41 \%)\end{array}$ \\
\hline $\begin{array}{l}\text { DVT } \\
\text { No } \\
\text { Yes }\end{array}$ & $\begin{array}{l}92(85.19 \%) \\
16(14.81 \%)\end{array}$ \\
\hline $\begin{array}{l}\text { PESI score }()^{-} \\
\text {Mean }(S D) \\
\text { Min; } \operatorname{Max} \\
\text { Median }(Q 1 ; Q 3)\end{array}$ & $\begin{array}{l}97.60(38.944) \\
29 ; 202 \\
93(75.5 ; 113.0)\end{array}$ \\
\hline $\begin{array}{l}\text { SPEST category } \\
0 \\
>=1\end{array}$ & $\begin{array}{l}26(24.07 \%) \\
82(75.93 \%)\end{array}$ \\
\hline $\begin{array}{l}\text { PESI nisk category } \\
\text { Risk low }(I+I I) \\
\text { Risk int }(I I+I V) \\
\text { Risk high }(V)\end{array}$ & $\begin{array}{l}41(37.96 \%) \\
45(41.67 \%) \\
22(20.37 \%)\end{array}$ \\
\hline $\begin{array}{l}\left.\text { BMI }\left(\mathrm{kg} / \mathrm{m}^{2}\right) \mathrm{T}^{3}\right)^{-} \\
\text {Mean }(S D) \\
\text { Min; Max } \\
\text { Median }(Q 1 ; Q 3)\end{array}$ & $\begin{array}{l}28.41(5.788) \\
21 ; 42 \\
26(24 ; 33)\end{array}$ \\
\hline $\begin{array}{l}\text { Cancer history or active cancer } \\
\text { No } \\
\text { Yes }\end{array}$ & $\begin{array}{l}95(87.96 \%) \\
13(12.04 \%)\end{array}$ \\
\hline $\begin{array}{l}\text { Atrial fibrilation } \\
\text { No } \\
\text { Yes }\end{array}$ & $\begin{array}{l}95(87.96 \%) \\
13(12.04 \%)\end{array}$ \\
\hline \begin{tabular}{|l} 
Heart failure(NYHA class) \\
0 \\
1 \\
2 \\
3 \\
4
\end{tabular} & $\begin{array}{l}33(30.56 \%) \\
1(0.93 \%) \\
50(46.30 \%) \\
20(18.52 \%) \\
1(3.70 \%)\end{array}$ \\
\hline $\begin{array}{l}\text { History of myocardial infarction } \\
\text { No } \\
\text { Yes }\end{array}$ & $\begin{array}{l}101(93.52 \%) \\
7(6.48 \%)\end{array}$ \\
\hline $\begin{array}{l}\text { Stroke history } \\
\text { No } \\
\text { Yes }\end{array}$ & $\begin{array}{l}99(91.67 \%) \\
9(8.33 \%)\end{array}$ \\
\hline $\begin{array}{l}\text { Chronic venous insufficiency (CEAP class) } \\
<=2 \\
>2\end{array}$ & $\begin{array}{l}95(88.96 \%) \\
13(12.04 \%)\end{array}$ \\
\hline $\begin{array}{l}\text { Diabetes mellitus } \\
\text { No } \\
\text { Yes }\end{array}$ & $\begin{array}{l}86(79.63 \%) \\
22(20.37 \%)\end{array}$ \\
\hline $\begin{array}{l}\text { Ymmobilization } \\
\text { No } \\
\text { Yes }\end{array}$ & $\begin{array}{l}102(94.44 \%) \\
6(5.56 \%)\end{array}$ \\
\hline $\begin{array}{l}\text { COPD } \\
\text { No } \\
\text { Yes }\end{array}$ & $\begin{array}{l}97(89.81 \%) \\
11(10.19 \%)\end{array}$ \\
\hline $\begin{array}{l}\text { Obesity } \\
\text { No } \\
\text { Yes } \\
\text { Grade } 1 \text { (\#) } \\
\text { Grade } 2 \text { (\#) } \\
\text { Grade } 3 \text { (\#)-morbid obesity }\end{array}$ & $\begin{array}{l}69(63.89 \%) \\
39(36.11 \%) \\
20(51.28 \%) \\
14(35.90 \%) \\
5(12.82 \%) \\
\end{array}$ \\
\hline
\end{tabular}

Table 1

SUMMARY OF BASELINE CHARACTERISTICS 


\begin{tabular}{|c|c|c|c|}
\hline & $\begin{array}{l}\text { Adult patients } \\
(\mathrm{N}=44)\end{array}$ & $\begin{array}{l}\text { Elderly patients } \\
(\mathrm{N}=64)\end{array}$ & p-value \\
\hline $\begin{array}{l}\text { Gender } \\
\text { Male } \\
\text { Female }\end{array}$ & $\begin{array}{l}25(56.82 \%) \\
19(43.18 \%)\end{array}$ & $\begin{array}{l}26(40.63 \%) \\
38(59.38 \%)\end{array}$ & 0.098 \\
\hline $\begin{array}{l}\text { PESI score }(*) \\
n \\
\text { Mean }(S D) \\
\text { Min; Max } \\
\text { Median }(Q 1 ; Q 3)\end{array}$ & $\begin{array}{l}44 \\
80.02(40.367) \\
29 ; 179 \\
70(48.5 ; 101.5)\end{array}$ & $\begin{array}{l}64 \\
109.69(33.158) \\
67 ; 202 \\
98.5(86.5 ; 121.0)\end{array}$ & $<0.001$ \\
\hline $\begin{array}{l}\text { sPESI category } \\
0 \\
>=1\end{array}$ & $\begin{array}{l}17(38.64 \%) \\
27(61.36 \%)\end{array}$ & $\begin{array}{l}9(14.06 \%) \\
55(85.94 \%)\end{array}$ & 0.003 \\
\hline $\begin{array}{l}\text { PESI risk category } \\
\text { Risk low }(I+I I) \\
\text { Risk int }(I I+I V) \\
\text { Risk high }(V)\end{array}$ & $\begin{array}{l}28(63.64 \%) \\
9(20.45 \%) \\
7(15.91 \%)\end{array}$ & $\begin{array}{l}13(20.31 \%) \\
36(56.25 \%) \\
15(23.44 \%)\end{array}$ & $<0.001$ \\
\hline $\begin{array}{l}\text { CT PROX } \\
\text { No } \\
\text { Yes }\end{array}$ & $\begin{array}{l}19(43.18 \%) \\
25(56.82 \%)\end{array}$ & $\begin{array}{l}35(54.69 \%) \\
29(45.31 \%)\end{array}$ & 0.900 \\
\hline $\begin{array}{l}\text { CT_LOBAR } \\
\text { No } \\
\text { Yes }\end{array}$ & $\begin{array}{l}31(70.45 \%) \\
13(29.55 \%)\end{array}$ & $\begin{array}{l}48(75.00 \%) \\
16(25.00 \%)\end{array}$ & 0.600 \\
\hline $\begin{array}{l}\text { CT_DISTAL } \\
\text { No } \\
\text { Yes }\end{array}$ & $\begin{array}{l}38(88.64 \%) \\
6(13.64 \%)\end{array}$ & $\begin{array}{l}45(70.31 \%) \\
19(29.69 \%)\end{array}$ & 0.052 \\
\hline
\end{tabular}

\begin{tabular}{|c|c|c|c|}
\hline & $\begin{array}{l}\text { Adult patients } \\
(\mathrm{N}=44)\end{array}$ & $\begin{array}{l}\text { Elderly patients } \\
(\mathrm{N}=64)\end{array}$ & p-value \\
\hline $\begin{array}{l}\text { Recurrent VTE } \\
\text { No } \\
\text { Yes }\end{array}$ & $\begin{array}{l}41(93.18 \%) \\
3(6.82 \%)\end{array}$ & $\begin{array}{l}61(95.31 \%) \\
3(4.69 \%)\end{array}$ & 0.635 \\
\hline $\begin{array}{l}\text { Asimptomatic } \\
\text { No } \\
\text { Yes }\end{array}$ & $\begin{array}{l}43(97.73 \%) \\
1(2.27 \%)\end{array}$ & $\begin{array}{l}63(98.44 \%) \\
1(1.56 \%)\end{array}$ & 0.788 \\
\hline $\begin{array}{l}\text { Dispnea } \\
\text { No } \\
\text { Yes }\end{array}$ & $\begin{array}{l}6(13.64 \%) \\
38(86.36 \%)\end{array}$ & $\begin{array}{l}4(6.25 \%) \\
60(93.75 \%)\end{array}$ & 0.193 \\
\hline $\begin{array}{l}\text { Pleuritic chest pain } \\
\text { No } \\
\text { Yes }\end{array}$ & $\begin{array}{l}23(52.27 \%) \\
21(47.73 \%)\end{array}$ & $\begin{array}{l}43(67.19 \%) \\
21(32.81 \%)\end{array}$ & 0.118 \\
\hline $\begin{array}{l}\text { Cough } \\
\text { No } \\
\text { Yes }\end{array}$ & $\begin{array}{l}38(86.36 \%) \\
6(13.64 \%)\end{array}$ & $\begin{array}{l}53(82.81 \%) \\
11(17.19 \%)\end{array}$ & 0.619 \\
\hline $\begin{array}{l}\text { Sincope } \\
\text { No } \\
\text { Yes }\end{array}$ & $\begin{array}{l}40(90.91 \%) \\
4(9.09 \%)\end{array}$ & $\begin{array}{l}59(92.19 \%) \\
5(7.81 \%)\end{array}$ & 0.813 \\
\hline $\begin{array}{l}\text { Infection } \\
\text { No } \\
\text { Yes }\end{array}$ & $\begin{array}{l}35(76.85 \%) \\
9(23.15 \%)\end{array}$ & $\begin{array}{l}48(92.19 \%) \\
16(7.81 \%)\end{array}$ & 0.582 \\
\hline $\begin{array}{l}\text { Palpitation } \\
\text { No } \\
\text { Yes }\end{array}$ & $\begin{array}{l}32(72.73 \%) \\
12(27.27 \%)\end{array}$ & $\begin{array}{l}52(81.25 \%) \\
12(18.75 \%)\end{array}$ & 0.295 \\
\hline $\begin{array}{l}\text { Death } \\
\text { No } \\
\text { Yes }\end{array}$ & $\begin{array}{l}42(95.45 \%) \\
2(4.55 \%)\end{array}$ & $\begin{array}{l}61(95.31 \%) \\
3(4.69 \%)\end{array}$ & 0.972 \\
\hline $\begin{array}{l}\text { Pulmonary infarction } \\
\text { No } \\
\text { Yes }\end{array}$ & $\begin{array}{l}39(88.64 \%) \\
5(11.36 \%)\end{array}$ & $\begin{array}{l}59(92.19 \%) \\
5(7.81 \%) \\
\end{array}$ & 0.532 \\
\hline
\end{tabular}

Table 2

COMPARISONS OF ADULT AND ELDERLY PATIENTS
Table 3

SYMPTOMS AND COMORBIDITIES OF ELDERLY PATIENTS
BMI was about $28 \mathrm{~kg} / \mathrm{m}^{2}$ which is consistent with overweight patients. The increase of BMI was associated in several studies with an increased risk of $P E$, some authors proposing that the vascular inflammatory state being one of the predisposing factors or insulin resistance [8-9].

In our analysis elderly patients higher CRP $(p=0.032)$. This fact is supported by several explanations, such as larger PEs that impact the pulmonary vasculature, more rigid vessels or a diminished right ventricle compliance or a combination of these, which can be explained by concomitant infection or other types of inflammation or even endothelial dysfunction, but is helpful in predicting the severity having moderate association with PEs $[10,13]$.

We observed a significant statistical result for the level of serum hemoglobin which correlates with the more proximal pulmonary embolism in the elderly versus the adult group. Adult patients are predisposed to anemia through a myriad of factors starting with deficient alimentation and other chronic diseases. Anemia is important when the need for anticoagulation in the prevailing therapeutic decision, being associated with a worse prognostic. In our study the RDW parameter had an inverse correlation with the size of the pulmonary 


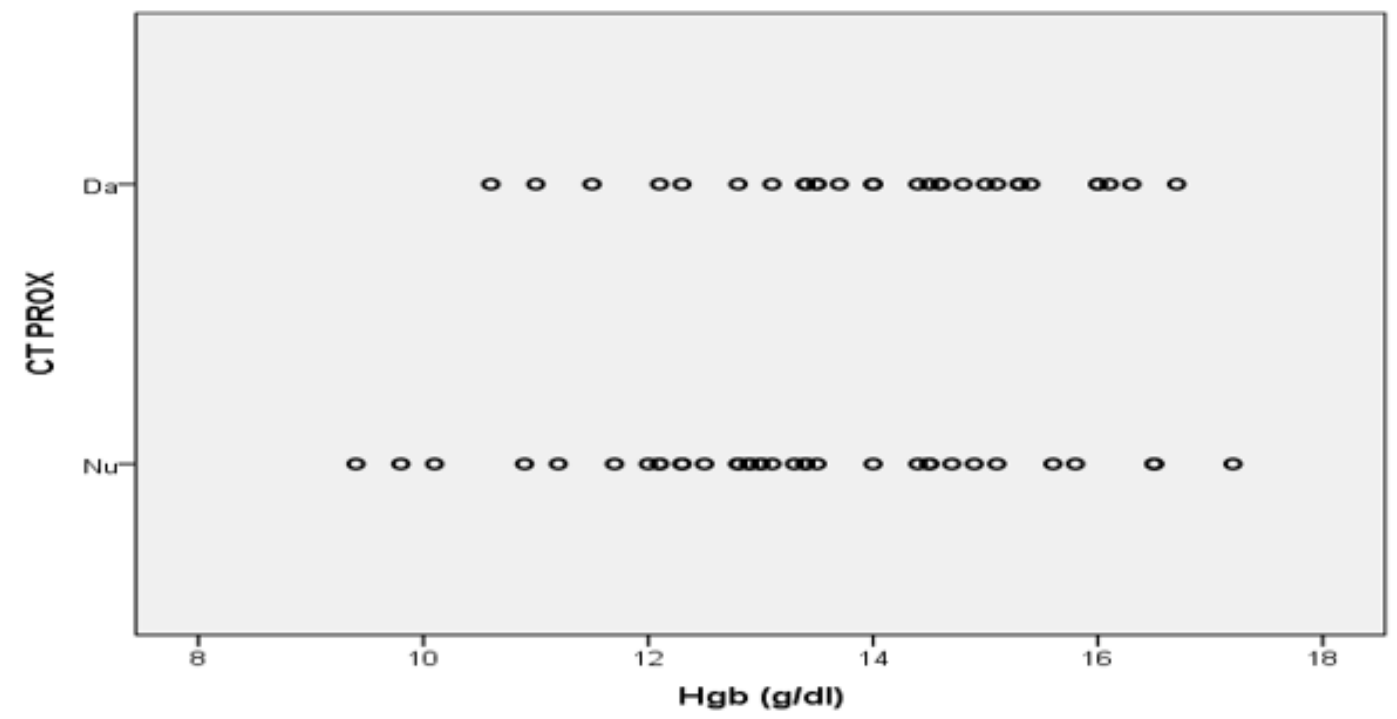

Fig. 1. Correlation between hemoglobin and

CT PROX for elderly patients $(\rho=0.262, p=0.037$

Table 4

SUMMARY OF CORRELATIONS BETWEEN PLD RISKS WITH HEMOGLOBIN, RDW AND LEUCOCYTE FOR ADULT AND ELDERLY PATIENTS; TW O-TAILED P-VALUES AND SPEARMAN CORRELATION COEFFICIENT ARE PRESENTED. SIGNIFICANT CORRELATIONS ARE BOLDED

\begin{tabular}{|c|c|c|c|c|}
\hline & & CT_PROX & CT_LOBAR & CT_DISTAL \\
\hline \multirow[t]{2}{*}{ Hemoglobin (g/dl) } & Adult patients $(\mathrm{N}=44)$ & $\rho=0.270, p=0.077$ & $\begin{array}{l}\rho=-0.185 \\
p=0.230\end{array}$ & $\begin{array}{l}\rho=-0.144 \\
p=0.352\end{array}$ \\
\hline & Elderly patients $(\mathrm{N}=64)$ & $\rho=0.262, p=0.037$ & $\begin{array}{l}\rho=-0.128 \\
p=0.313\end{array}$ & $\begin{array}{l}\rho=-0.164 \\
p=0.196\end{array}$ \\
\hline \multirow[t]{2}{*}{ Leucocytes xl000 } & Adult patients $(\mathrm{N}=44)$ & $\rho=0.183, p=0.236$ & $\begin{array}{l}\rho=-0.118, \\
p=0.447\end{array}$ & $\begin{array}{l}\rho=-0.107, \\
p=0.490\end{array}$ \\
\hline & Elderly patients $(\mathrm{N}=64)$ & $\rho=0.138, p=0.275$ & $\rho=0.012, p=0.927$ & $\begin{array}{l}\rho=-0.162 \\
p=0.201\end{array}$ \\
\hline \multirow[t]{2}{*}{$\mathrm{RDW}(\%)$} & Adult patients $(\mathrm{N}=44)$ & $\rho=-0.004, p=0.981$ & $\rho=0.035, p=0.820$ & $\begin{array}{l}\rho=-0.042, \\
p=0.788\end{array}$ \\
\hline & Elderly patients $(\mathrm{N}=64)$ & $\rho=-0.026, p=0.836$ & $\rho=0.178, p=0.160$ & $\begin{array}{l}\rho=-0.140 \\
p=0.270\end{array}$ \\
\hline
\end{tabular}

embolism, but it did not achieve a statistical significance. Several studies have shown that there is some degree of correlation with this parameter [14,15].

Regarding CKD patients, which were excluded from our study, especially those with a eGFR $<15 \mathrm{~mL} / \mathrm{min}$ and dialysis patients, is known that they have a nearly 2 fold increased hazard ratio(HR) of PE and a 2.5 fold increased mortality from PE compared with those without clinical kidney disease [16-20]. On the other hand, HD is associated with a higher risk of PE than PD [20]. In these patients, GFR alone proved to be a reliable follow-up parameter, as a marker for CV events [16-19]. For this special population, in order to establish a better risk profile, further studies are needed. Appropriate preventive measures are required to reduce the potential pulmonary embolism development and to avoid PE mortality, both by using multimodal imaging and proper medical management [17-20].

\section{Conclusions}

In the elderly patients with pulmonary thromboembolism, the more reliable are the clinical and complete blood count as tools for evaluating the severity.

Limitations: We found several limitations of this study such as the small number of patients, could reduce the power of this study, while some studies have found some relationship with the RDW index, we found no correlations even in the elderly patients. The grouping of patients based on their eGFR was based from a more clinical point of view, as patients for example with stages I and II of renal disease have almost no clinical features, while those with established chronic renal disease have other clinical profiles. This grouping could have impacted the statistical significance, but for a clinician in the emergency situation the simpler the algorithm the better is to guide treatment.

\section{References}

1.BENJAMIN EJ, MUNTNER P, ALVARO A ET AL, Heart Disease and Stroke Statistics-2019 Update: A Report from the American Heart Association Circulation. 2019; 139: e56-e528 Mar 2019

2. COHEN AT, AGNELLI G, ANDERSON FA ET AL. Venous thromboembolism (VTE) in Europe. The number of VTE events and associated morbidity and mortality. Thromb Haemost2007;98(4):756 764.

3.KONSTANTINIDES SV, TORBICKI A, AGNELLI G ET AL. 2014 ESC guidelines on the diagnosis and management of acute pulmonary embolism, Eur Heart J 2014 Nov 14;35(43):3033-69, 3069a-3069k.

4. LE GAL G, RIGHINI M, ROY PM, ET AL. Prediction of pulmonary embolism in the emergency department: the revised Geneva score. Ann Intern Med2006;144(3):165 - 171.

5. ROBERT-EBADI H, MOSTAGUIR K, HOVENS MM ET AL. Assessing clinical probability of pulmonary embolism: prospective validation of the simplified Geneva score.J ThrombHaemost. 2017 Sep;15(9):17641769.

6. B-LOHLAVEK J, DYTRYCH V, LINHART A. Pulmonary embolism, part I: Epidemiology, risk factors and risk stratification, pathophysiology, clinical presentation, diagnosis and nonthrombotic pulmonary embolism. ExpClinCardiol. 2013;18(2):129-138.

7. KILICT, GUNEN H, GULBASG, HACIEVLIYAGIL SS, OZER A. Prognostic role of simplified Pulmonary Embolism Severity Index and the European Society of Cardiology Prognostic Model in short- and longterm risk stratification in pulmonary embolism. Pak J Med Sci. 
2014;30(6):1259-1264. doi:10.12669/pjms.306.5737

8. SLOAN M, SHETH N, LEE GC. Is Obesity Associated with Increased Risk of Deep Vein Thrombosis or Pulmonary Embolism After Hip and Knee Arthroplasty? A Large Database Study ClinOrthopRelat Res. 2019Mar;477(3):523-532.

9. YANG G, DE STAERCKE C, HOOPER WC. The effects of obesity on venous thromboembolism: A review. Open J Prev Med. 2012;2(4):499509. doi:10.4236/ojpm.2012.24069

10. KERSTIN HOGG. CRP in the diagnosis of pulmonary embolism Emergency Medicine J ournal 2010; 27: A4. December 26, 2010

11.MASOTTI L, RAY P, RIGHINI M, ET AL. Pulmonary embolism in the elderly: a review on clinical, instrumental and laboratory presentation. Vasc Health Risk Manag. 2008;4(3):629-636.

12.KOKTURK N, OGUZULGEN IK, DEMIR N, ET AL. Differences in clinical presentation of pulmonary embolism in older vs younger patients. Circ J. 2005; 69:981-6.

13.ABUL Y, KARAKURT S, OZBEN B, ET AL. C-Reactive Protein in Acute Pulmonary Embolism Journal of Investigative Medicine 2011;59:8-14.

14.HAMMONS, L., FILOPEI, J., STEIGER, D. ET AL. J Thromb Thrombolysis (2019).

15. ZORLU A ET AL Usefulness of Admission Red Cell Distribution
Width as a Predictor of Early Mortality in Patients with Acute Pulmonary Embolism. American J ournal of Cardiology, Volume 109, Issue 1, 128 $-134$.

16. APOSTOL, A., CHISAVU, L, ALBULESCU, N., STOIAN, D., SCHILLER, A., RAS Inhibition in Haemodialysis Patients. Rev. Chim. (Bucharest), 70 no. 2, 2019, pg. 442-444.

17. IVAN, V.S., ALBULESCU, N., ALBULESCU, I.R., APOSTOL, A., BUZAS, R., SCHILLER, A., TIMAR, R., LIGHEZAN, D., IVAN, M.V., Predictive Value of Several Echo Parameters for Cardiovascular Events in Hemodialysis Patients with Mid-range and Preserved Ejection Fraction Heart Failure. Rev. Chim. (Bucharest), 70, no. 4, 2019, p.1479-1484. 18. ALBULESCU, N., APOSTOL, A., ALBULESCU, I.R., MIHAESCU, A., SCHILLER, A., TIMAR, R., Furosemide Pharmacodynamics and Cardiovascular Effects in Hemodialysis Patients. Rev. Chim. (Bucharest), 70, no. 3, 2019, p. 973-976.

19. MUNTEANU, M., APOSTOL, A., IVAN, M.V., New Considerations Regarding Chronic Kidney Disease, Cardiovascular Disease and Dyslipidemia in Diabetic Patients. Rev. Chim. (Bucharest), 69 no 8, 2018 p.2064.

20. WANG IK, SHEN TC, MUO CH, YEN TH, SUNG FC. Risk of pulmonary embolism in patients with end-stage renal disease receiving longterm dialysis. Nephrology Dialysis Transplantation, Volume 32, Issue 8, August 2017, Pages 1386-1393.

Manuscript received: 14.02 .2019 